\title{
MOLECULAR EPIDEMIOLOGY OF ANIMAL RABIES IN THE SEMIARID REGION OF PARAÍBA, NORTHEASTERN BRAZIL
}

\author{
A.A.B. Gomes ${ }^{1}$, M.L.C.R. Silva ${ }^{1}$, F. Bernardi ${ }^{2}$, T. Sakai ${ }^{3}$, T. Itou ${ }^{3}$, F.H. Ito $^{4}$ \\ ${ }^{1}$ Universidade Federal de Campina Grande, Unidade Acadêmica de Medicina Veterinária, Centro de Saúde \\ e Tecnologia Rural, Caixa Postal 64, CEP 58700-970, Patos, PB, Brasil. E-mail: alberigomes@bol.com.br
}

\begin{abstract}
In the semiarid of the state of Paraíba, the anti-rabies vaccination is not common, most of the local inhabitants who deal with the animals do not know the incidence of the disease in the region. In this study, samples of foxes (Pseudalopexvetulus), insectivorous bats (Molossus molossus), raccoons (Procyon cancrivorous) and domestic animals brains were submitted to the diagnosis of rabies, by using the direct fluorescent antibody technique (d-FAT) and mouse inoculation test (MIT). Of the 581 examined materials, $50(8.60 \%)$ were positive for d-FAT and 47 (8.09\%) for MIT. From the positive samples for rabies, RNAs were extracted and transformed to CDNA, at the Laboratory of Rabies/Faculdade de Medicina Veterinária e Zootecnia/USP, SP. The phylogenetic characterization of the $\mathrm{N}$ gene was performed at the Universidade de São Paulo, Faculdade de Medicina Veterinária e Zootecnia, Departamento de Medicina Veterinária Preventiva e Saúde Animal, Universidade Nihon, Faculdade de Ciências Bioresource, Fujisawa, Kanagawa, Japão. Based on the results of genotyping and phylogenetic analyzes, it is concluded that the epidemiology of rabies is complex in the semiarid of Paraíba, with different viral variants being maintained in domestic dogs, foxes, insectivorous bats and vampire bats. All the isolates examined belong to the genotype I of the genus Lyssavirus and it is possible to state that in the region, foxes are important sylvatic reservoirs of the rabies virus.
\end{abstract}

KEY WORDS: Lyssavirus, wild canids, domestic animal, insectivorous bats.

\section{RESUMO}

EPIDEMIOLOGIA MOLECULAR DA RAIVA ANIMAL NO SEMIÁRIDO DA PARAÍBA, NORDESTE DO BRASIL. No semiárido do Estado da Paraíba, a vacinação antirrábica não é comum, a maioria dos habitantes locais que lidam com os animais não conhece a incidência da doença na região. Neste estudo, amostras do cérebro de raposas (Pseudalopex vetulus), de morcegos insetívoros (Molossus molossus), de guaxinins (Procyon cancrivorous) e de animais domésticos foram submetidas ao diagnóstico da raiva, pela técnica de imunofluorescência direta (IFD) e inoculação intracerebral em camundongos (ICC). Dos 581 materiais examinados, 50 (8,60\%) foram positivos para IFD e 47 (8,09\%) para o ICC. Das amostras positivas para raiva, os RNAs foram extraídos e transformados em DNA, no Laboratório de Raiva/Faculdade de Medicina Veterinária e Zootecnia/ USP, SP. A caracterização filogenética do gene N foi realizada no Centro de Investigação Veterinária, Departamento de Medicina Veterinária Preventiva e Saúde Animal, Faculdade de Ciências Bioresource, Nihon University, Fujisawa, Kanagawa, Japão. Com base nos resultados das análises filogenéticas e genotipagem, conclui-se que a epidemiologia da raiva é complexa no semiárido da Paraíba, com diferentes variantes virais sendo mantidas em cães domésticos, raposas, morcegos insetívoros e morcegos hematófagos. Todos os isolados analisados pertencem ao genótipo I do gênero Lyssavirus, e é possível afirmar que, na região, as raposas são importantes reservatórios silvestres do vírus da raiva.

PALAVRAS-CHAVE: Lyssavirus, canídeos silvestres, animais domésticos e morcegos insetívoros.

${ }^{2}$ Centro de Vigilância Sanitária e Controle de Zoonoses “Tereza Rodrigues de Camargo”, Ibiúna, SP, Brasil.

${ }^{3}$ Universidade Nihon, Faculdade de Ciências Bioresource, Fujisawa, Kanagawa, Japão.

${ }^{4}$ Universidade de São Paulo, Faculdade de Medicina Veterinária e Zootecnia, Departamento de Medicina Veterinária Preventiva e Saúde Animal, São Paulo, SP, Brasil. 
Rabies is an anthropozoonosis characterized by a fatal encephalomyelitis, caused by the virus strains of the Monegavirales order, Rhabdoviridae family, and Lyssavirus genus, which attack animals and human beings. The lethality is $100 \%$ in animals, the principal reservoirs are known to differ among regions of the world, but in Latin America, the classical genotype 1 virus strains occur in bats and other domestic and wild terrestrial mammals (NADIN-DAVIS, 2007).

The present work aimed to study the epidemiology of rabies in the semiarid of the state of Paraiba, contemplating the following aspects: to check the occurrence of rabies in the domestic animals of the region; to investigate the condition of "reservoir" of the virus in the wild canids; and to characterize phylogenetically and antigenically the rabies virus strains isolated from the semiarid.

In the period of 2001 to 2003, 287 roadkilled wild canids were gathered - hoary foxes (Pseudalopex vetulus) with authorization of IBAMA (n.332/2001). The highways used for the collections of roadkills were those that cut the semiarid of the state of Paraíba, in Patos neighborhood, between the South latitudes - $06^{\circ} 46^{\prime} 19^{\prime \prime}$ and $07^{\circ} 38^{\prime} 32^{\prime \prime}$ and longitudes West $-36^{\circ} 42^{\prime} 52^{\prime \prime}$ and $38^{\circ} 08^{\prime} 56^{\prime \prime}$. For the gathering of roadkills, the fleet of vehicles used for alternative transport serving Patos was employed. Each volunteer driver was alerted of the risks of transmission of diseases; instructions were previously received for realization of this task, and gloves and plastic bags were received for the collection of the roadkills. Every morning a patrol was carried out for the collection and shipment of carcasses to the laboratory. Eight raccoons (Procyon cancrivorous) roadkills were found in the same highways where foxes have been gathered, in the same period of the roadkill foxes collections and they were submitted for rabies diagnosis.

The capturing of non-hematophagous bats was carried using the "mist nets" at the entry of the animal facility building of the Centro de Saúde e Tecnologia Rural, of the Universidade Federal de Campina Grande (CSTR-UFCG), Patos, Paraíba. A total of 192 bats were captured and another 8 specimens found fallen in the urbane zone of Patos were directed to the laboratory by the residents of the city. All the examined bats were insectivorous, belonging to the family Molossidae, genus Molossus, and species Molossus molossus.

There were domestic animals subjected to the rabies diagnosis, 41 bovines, 11 equines, 5 asinines, 6 caprines, 5 ovines and 6 dogs received by the Veterinary Hospital of the CSTR-UFCG, all with suspicion of rabies.

Mouse inoculation test (MIT) was carried out in mice(FMVZ-USP Bioethics Commission permission $n^{\circ} 105 / 2002$ ) according to the methodology described by Koprowsкi (1996) and direct fluorescent antibody test (d-FAT) according to the technique described by DEAn et al. (1996).

RNAs were extracted directly from rabid mouse brain emulsions with virus at its first passage, with a commercial reagent kit (QIAamp Viral RNA Mini Kit., QIA-GEN K.K. Japan), according to the manufacturer's instructions, as described by ITо et al. (2003). After extracting the RNA, the materials were submitted to RT-PCR, according to the methodology described by ARAI et al. (1997), by employing a set of primers with nucleotide sequence 5'-3': CTAGGATTGACAAGATTTTGCTC, position 1516-1539, genomic RNA. The amplified products were sent to Veterinary Research Center, College of Bioresource Sciences of the Nihon University, Fujisawa, Kanagawa, Japan, and analyzed phylogenetically. Direct consensus sequencing of PCR products was performed with an automated sequencer (ABI PRISM ${ }^{\mathrm{TM}}$ 377 Genetic Analyzer, Applied Biosystems, PerkinElmer Corporation, Japan), using PRISMS Ready Reaction Dyedeoxy Terminator Cycle sequencing Kit(Applied Biosystems, Perkin-Elmer Corporation, Japan), according to the manufacturer's instructions, as described by ITO et al. (2001).

The analysis was carried out on 1,332 nucleotides of the $\mathrm{N}$ gene corresponding to nucleotides 891420 of the isolates included in this study. The results of the sequencing were compared to other Brazilian isolates and those strains isolated in the world, which were obtained from GenBank data base (http:/ / www.ncbi.nlm.nih.gov/Genbank/) and the analysis of the alignments of homologous sequences were made using CLUSTAL $X$ and the neighbor-joining method was used for constructing phylogenetic trees and based on Kimura-2 parameters (THOMPSON et al., 1997). The clusters in the phylogenetic trees were tested by the bootstrap method with 1,000 replications and bootstrap values greater than $70 \%$ for nucleoprotein were regarded as evidence for grouping. For graphic output, the TREEVIEW program was used (Hillis; BulL, 1993).

Of 581 materials subjected to d-FAT and MIT, 50 were diagnosed positive by d-FAT and 47 by MIT, corresponding to $8.60 \%$ and $8.09 \%$, respectively. Relatively to the species, $19 / 41(46.34 \%)$ of bovine; $12 / 287(4.18 \%)$ of fox; $1 / 5(20.00 \%)$ of ovine, $2 / 5(40.00 \%)$ and $2 / 6(33.33 \%)$ of canine samples presented positive results for both tests. Conflicting results, however, were found: $2 / 6(33.33 \%)$ of goats samples were positive in d-FAT and 1/ 6 (16.67\%) in MIT, 3/11 (27.27\%) of equines samples were positive in d-FAT and 2/11 (18.18\%) in MIT and 9/200 (4.50\%) insectivorous bats samples were positive in d-FAT and 8/200 (4.00\%) in MIT. Eight raccoons were diagnosed negative. 


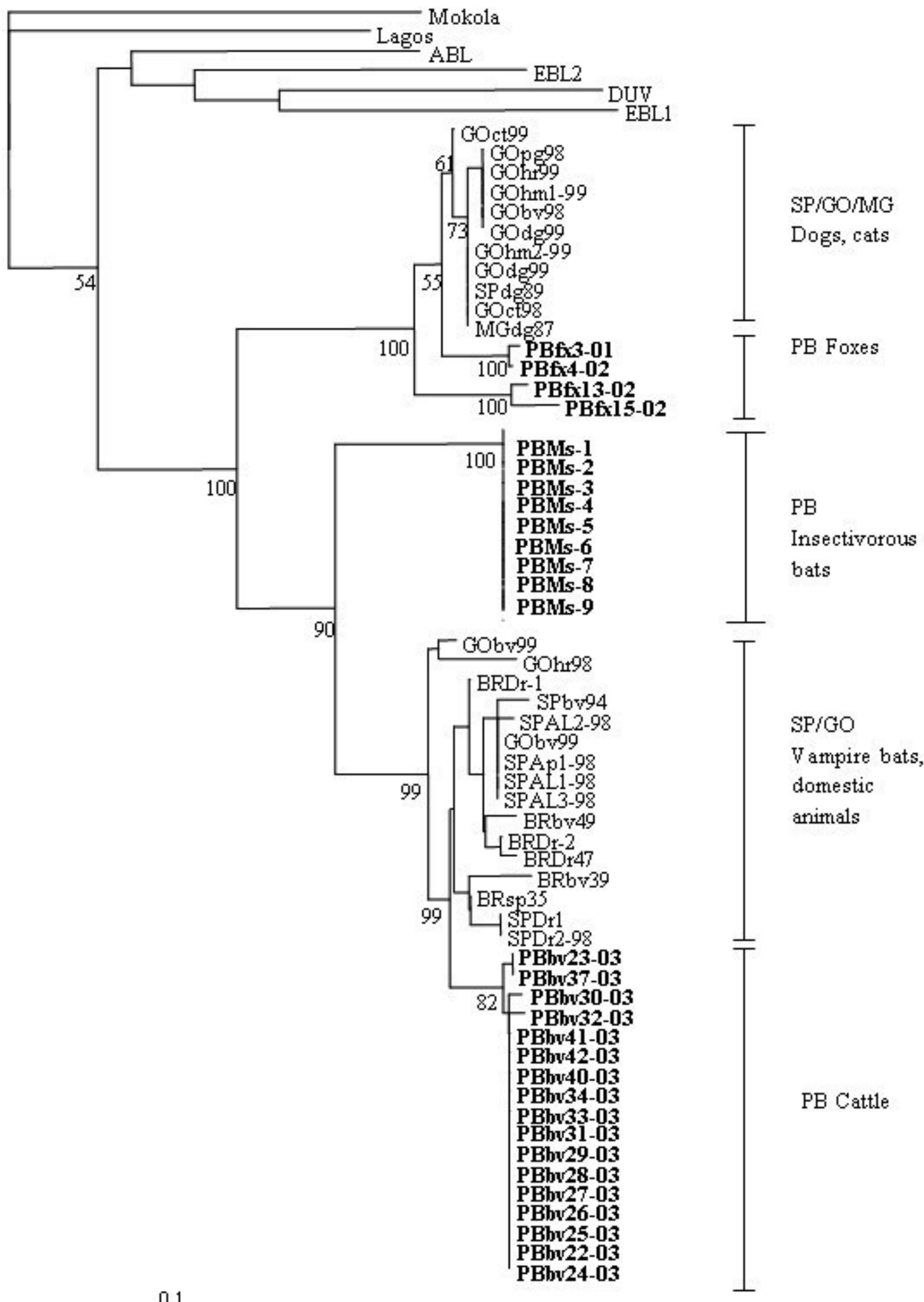

Fig. 1 - Dendrogram ilustrating the genetic established between rabies virus isolates, winth 100 replications in the "bootstrap". Viruses of the genus Lyssaviris, genotypes 1, 2, 3, 4, 5, 6 and 7 are distributed in the superior part of the tree. Grouping for similary of the proteins $\mathrm{N}$ gene, using a sequence of $203 \mathrm{bp}$, referring to viruses a isolated in the states of São Paulo (SP), Goiás (GO), Minas Gerais (MG) and Paraíba (PB) in dog (dg), cat (cty), human (hm), equine (hr), pig (pg), bovine (bv), fox (fx), M. molossus (Ms), D. rotavirus (Dr), Artbeus lituratus (At), A. planirostriz (Ap) and ovine (sp). It was considered Bootstrap value $>90 \%$ for 100 replications. 
All the positive samples in MIT presented a period of incubation of 7-16 days, in its first passage, with signs of excitement, bristling hairs, progressive slimming, paralysis and death 1-8 days after the beginning of the clinical signs. All MIT-positive samples were confirmed next by d-FAT. The results of the analysis of the N protein gene, taking the CVS strain as a reference, are represented in the dendrogram of the Figure 1. With the results obtained in the present study, it is possible to affirm that rabies in the semiarid region of Patos is caused by the classic rabies virus, genotype 1 Lyssavirus strains. There is an elevated risk of the transmission of the disease for human, because in the semiarid it is a habit to adopt cubs of wild animals for creation in captivity, although such a practice is prohibited by IBAMA. Other aggravating factors are the reports of aggression to the humans involving the wild canids and the great number of insectivorous bats living in urbanized areas, and vampire bats present in rural environments of the region.

Table 1 - List of the rabies virus isolates submitted to phylogenetic analysis after sequencing, with the respective year of isolation, state of origin and host species.

\begin{tabular}{|c|c|c|c|}
\hline $\begin{array}{l}\text { Name of the } \\
\text { isolates }\end{array}$ & $\begin{array}{c}\text { Year of } \\
\text { isolation }\end{array}$ & State & Host species \\
\hline PB fx3-01 & 2001 & Paraíba & Fox \\
\hline PB fx4-02 & 2002 & Paraíba & Fox \\
\hline PB Ms-1 & 2003 & Paraíba & M. molossus \\
\hline PB Ms-2 & 2003 & Paraíba & M. molossus \\
\hline PB Ms-3 & 2003 & Paraíba & M. molossus \\
\hline PB Ms-4 & 2003 & Paraíba & M. molossus \\
\hline PB Ms-5 & 2003 & Paraíba & M. molossus \\
\hline PB Ms-6 & 2003 & Paraíba & M. molossus \\
\hline PB fx-13-02 & 2002 & Paraíba & Fox \\
\hline PB fx15-02 & 2002 & Paraíba & Fox \\
\hline PB Ms-7 & 2003 & Paraíba & M. molossus \\
\hline PB Ms-8 & 2003 & Paraíba & M. molossus \\
\hline PB Ms-9 & 2003 & Paraíba & M. molossus \\
\hline PBbv22-03 & 2003 & Paraíba & Cattle \\
\hline PBbv23-03 & 2003 & Paraíba & Cattle \\
\hline PBbv24-03 & 2003 & Paraíba & Cattle \\
\hline PBbv25-03 & 2003 & Paraíba & Cattle \\
\hline PBbv26-03 & 2003 & Paraíba & Cattle \\
\hline PBbv27-03 & 2003 & Paraíba & Cattle \\
\hline PBbv28-03 & 2003 & Paraíba & Cattle \\
\hline PBbv29-03 & 2003 & Paraíba & Cattle \\
\hline PBbv30-03 & 2003 & Paraíba & Cattle \\
\hline PBbv31-03 & 2003 & Paraíba & Cattle \\
\hline PBbv32-03 & 2003 & Paraíba & Cattle \\
\hline PBbv33-03 & 2003 & Paraíba & Cattle \\
\hline PBbv34-03 & 2003 & Paraíba & Cattle \\
\hline PBbv37-03 & 2002 & Paraíba & Cattle \\
\hline PBbv40-03 & 2000 & Paraíba & Donkey \\
\hline PBbv41-03 & 2003 & Paraíba & Cattle \\
\hline PBbv42-03 & 2002 & Paraíba & Cattle \\
\hline
\end{tabular}

The intracerebral inoculations of the suspensions prepared from the brains of different animal species provoked the death of the mice with varied periods of incubation and clinical manifestations, although typical for the species. The observed limits must not be considered different from those observed by others, small variations can be associated both to the dose of virus (CARNIELI JUNIOR et al., 2009) and to adaptation of the isolates to the biological system used. All the isolates were positive by d-FAT, with formation of varied size and shape of inclusion bodies. Discrepant results between d-FAT and MIT were observed with the isolates derived from goats, equine and insectivorous bats, respectively. These results probably happened due to the inadequate conservation of the materials, consequent to the high temperature and advanced state of putrefaction.

The sequencing of the $\mathrm{N}$ gene (Fig. 1, Table 1) shows that at least 5 different groups of virus circulate in the species of the region: one in dog, two in foxes, one in insectivorous bats and one in vampire bats. According to the dendrograms, it is possible to realize that the isolates analyzed form a group that has a common ancestral, hypothetically pertaining to the genotype 1 of the genus Lyssavirus. This group is differentiated in two branches: one associated to the carnivores and other to the chiropterans of several species. This observation suggests that at least two groups of virus coexist in the same region, being one in carnivores and other in bats. The two groups, however, present a genetic variability. The group of the carnivores is divided in three different branches, constituted by the domestic carnivores "dogs" and other two for foxes, "fox 1" and "fox 2". However, the group " fox 2 " is nearer of the group "dog" by the homology of nucleotides of the $\mathrm{N}$ gene, agreeing with the results of BERNARDI et al. (2005), SHOJI et al. (2006), NADin-Davis (2007) and KobaYASHI et al. (2007).

In this study, the results agreed with the results of CARNIELI JUNIOR et al. (2008) and CARNIELLI JUNIOR et al. (2009) with analysis of the $\mathrm{N}$ gene of rabies virus isolated from wild canids of the northeastern Brazil, there were found two distinct groups: one associated to the dogs and the other to the wild canids, these groups presenting subdivisions that suggest adaptation of the virus to the species. The spreading of the information on the incidence of rabies in the semiarid region increased the interest on the disease. This fact demonstrates that there is the need of the diagnostic service in the state of Paraiba. The passive surveillance is inoperative in certain circumstances and the active search of rabies in wild animals allowed having a more accurate vision of the disease occurrence in the region.

This paper is agree with Ethical principles in animal reserch adopted by Bioethic Commission 
of the Faculdade de Medicina Veterinária of the Universidade de São Paulo, protocol n 105/2002.

\section{REFERENCES}

ARAI, Y.T.; KAMEOKA, Y.; HORIMOTO, T.; YAMAMOTO, K.; YABE, S.; NAKAYAMA, M.; TASHIRO, M. Nucleoprotein gene analysis of fixed and street rabies virus variants using RT-PCR. Archives of Virology, v.142, p.1787-1796, 1997.

BERNARDI, F., NADIN-DAVIS, S.A.; WANDELER, A.I.; ARMSTRONG, J.; GOMES, A.A.B.; LIMA F.S.; NOGUEIRA F.R.B.; ITO, F.H. Antigenic and genetic characterization of rabies viruses isolated from domestic and wild animals of Brazil identifies the hoary fox as a rabies reservoir. Journal of General Virology, v.86, p.31533162, 2005.

CARNIELI JÚNIOR, P.; FAHL, W.O.; CASTILHO, J.G.; OLIVEIRA, R.N.; MACEDO, C.I.; DURYMANOVA, E.; JORGE, R.S.P.; MORATO, R.G.; SPÍNDOLA, R.O.; MACHADO, L.M.; CARRIERI, M.L.; KOTAIT, I. Characterization of rabies vírus isolated from canids and identification of the main wild canid host in Northeastern Brazil. Virus Research, v.131, p.33-46, 2008.

CARNIELI JÚNIOR, P.; CASTILHO, J.G.; FAHL, W.O.; VÉRAS, N.M.C.; CARRIERI, M.L.; KOTAIT, I. Molecular characterization of rabies virus isolates from dogs and crab-eating foxes in Northeastern Brazil. Virus Research, v.141, p. 81-89, 2009.

DEAN, D.J.; ABELSETH, M.K.; ATANASIU, P. The fluorescent antibody test, In: MELSIN, F.X.; KAPLAN, M.M.; KOPROWSKI, H. (Ed.) Laboratory Techniques in Rabies. Geneva: World Health Organiazation, 1996. p.88-95.

HILLIS, D.M.; BULL, J.J. An empirical test of bootstrapping as a method for assessing confidence in phylogenetic analysis. Systematic Biology, v.42, p.182-192, 1993.

ITO, M.; ITOU, T.; SAKAI, T.; SANTOS, M.F.C.; ARAI, Y.T.; TAKASAKI, T.; KURANE, I; ITO, F.H. Detection of rabies virus RNA isolated from several species of animals in Brazil by RT-PCR. Journal of Veterinary Medicine Science, v.63, n.12, p.1309-1313, 2001.

ITO, M.; ITOU, T.; SHOJI Y.; SAKAI, T.; ITO, F.H.; ARAI,Y. T.; TAKASAKI, T.; KURANE, I. Discrimination between dog-related and vampire bat-related rabies viruses in Brazil by strain-specific reverse transriptasepolymerase chain reaction and restriction fragment length polymorphism analysis. Journal of Clinical Virology, v.26, p.317-330, 2003.

KOBAYASHI, Y.; INOUE, N.; SATO, G.; ITOU, T.; SANTOS, H.P.; BRITO, C.J.C.; GOMES, A.A.B.; SANTOS, M.F.C.; SILVA, M.V.; MOTA, C.M.; ITO, F.H.; SAKAI, T. Phylogenetic characterization of rabies virus isolated from carnivora in Brazil. Journal of Veterinary Medicine Science, v.69, p.691-696, 2007.

KOPROWSKI, H. The mouse inoculation test. In: MESLIN, F.X.; KAPLAN, M.M.; KOPROWSKI, H. (Ed.). Laboratory techiniques in rabies. 4.ed. Geneva: World Health Organization, 1996. p.80-87.

NADIN-DAVIS, S.A. Molecular Epidemiology. In: JACKSON, A.C.; WUNNER, W.H. (Ed.). Rabies. 2. ed. Amstedam: Elsevier Academic Press, 2007. p.69-122.

SHOJI, Y.; KOBAYASHI, Y.; SATO, G.; GOMES, A.A.B.; ITOU, T.; ITO, F.H.; SAKAI, T. Genetic and phylogenetic characterization of rabies virus isolates from wildlife and livestock in Paraiba, Brazil. Acta Virologica, v.50, n.1, p.33-37, 2006.

THOMPSON, J.D.; GIBSON, K.J.; PLEWNIAK, F.; JEANMOUGIN, F.; HIGGINS, D.G. Clustal X widows interface: Flexible strategies for multiple sequence alignment aided by quality analysis tools. Nucleic Acids Research, v.25, p.4876-4882, 1997.

Receveid on $16 / 6 / 11$

Accepted on 18/10/12 